\title{
Disseminated tuberculosis in relatively asymptomatic young woman
}

\author{
Sharath P Madhyastha, ${ }^{1}$ Vinaya Gopalaswamy, ${ }^{1}$ Raviraja V Acharya, ${ }^{1}$ \\ Akhila Doddamani
}

${ }^{1}$ Department of Internal Medicine, Kasturba Medical College, Manipal, Karnataka, India

${ }^{2}$ Department of Community Medicine, Kasturba Medical College, Manipal, Karnataka, India

Correspondence to Dr Sharath P Madhyastha, dr.sharathymc@gmail.com

Accepted 7 July 2017
CrossMark

To cite: Madhyastha SP, Gopalaswamy V, Acharya RV, et al. BMJ Case Rep Published Online First: [please include Day Month Year]. doi:10.1136/bcr-2017 219276

\section{DESCRIPTION}

A previously healthy 20-year-old woman presented to the emergency department with a history of one episode of generalised tonicclonic seizure. No history of fever or constitutional symptoms. At admission, she was haemodynamically stable and Glasgow Coma Scale was 8 , with no focal neurological deficits. For the workup of seizures, MRI brain (figure 1) was done which revealed multiple ring-enhancing lesions in bilateral temporal, frontal and right parietal lobes. Cerebrospinal fluid examination showed normal cell count with high protein $(84 \mathrm{mg} / \mathrm{dL})$ and normal glucose levels $(43 \mathrm{mg} / \mathrm{dL})$, and high adenosine deaminase $(9.3 \mathrm{U} / \mathrm{L})$ level. Chest X-ray showed (figure 2A) miliary mottling which was confirmed by contrast-enhanced CT (CECT) chest (figure 2B and C). CECT abdomen (figure $3 \mathrm{~A}$ and $\mathrm{B}$ ) revealed thick-walled multiloculated collection $(7.3 \times 8.4 \times 14.2 \mathrm{~cm})$ with thick internal septations in the left lumbar and iliac fossa region. Pelvic collections were drained with an image-guided pig tail insertion and pus was sent for analysis which revealed acid-fast bacilli. The Mycobacterium tuberculosis was sensitive to isoniazid and rifampicin. HIV ELISA was non-reactive, CD4 counts and her immunoglobulin levels were normal. An enquiry about her immunisation status revealed that she had received Bacillus Calmette-Guerin vaccination at birth. The patient was treated with antitubercular therapy, steroids and antiepileptic drugs. Clinically, sensorium improved and she was discharged after 2 weeks with an advice to

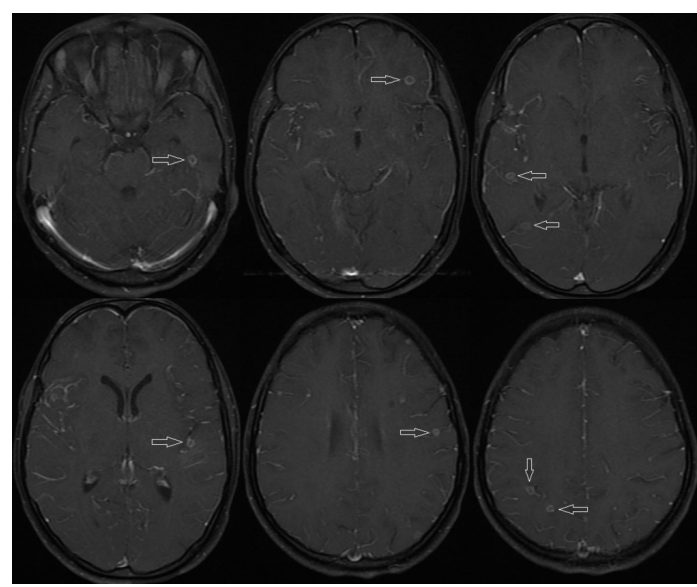

Figure 1 MRI brain (T1-weighted images)_axial view showing multiple ring-enhancing lesions (arrows).

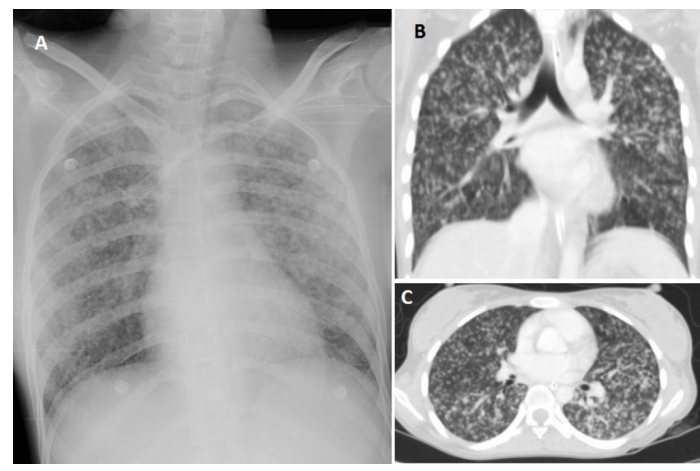

Figure 2 Chest X-ray (A) and CT chest (B-coronal, $\mathrm{C}$-axial view) showing miliary nodules involving both lungs.

continue antitubercular therapy and a tapering dose of steroids. Follow-up images (figure 4) after 3 months showed complete resolution of pelvic collection.

Tuberculosis is widely prevalent in India and accounts for one-fourth of the global TB burden. ${ }^{1}$ Disseminated tuberculosis refers to concurrent involvement of at least two non-contiguous organ sites of the body. It also refers to involvement of blood or bone marrow by tuberculosis process. Miliary tuberculosis is a form of disseminated tuberculosis due to haematogenous dissemination of tubercle bacilli. This results in tiny discrete foci usually the size of millet seeds, uniformly distributed in the lungs and other viscera. $^{2}$

Disseminated and miliary tuberculosis can involve any organ in the body. Our patient had multiple tuberculomas in the brain, miliary tuberculosis and pelvic collection. Diagnosis is

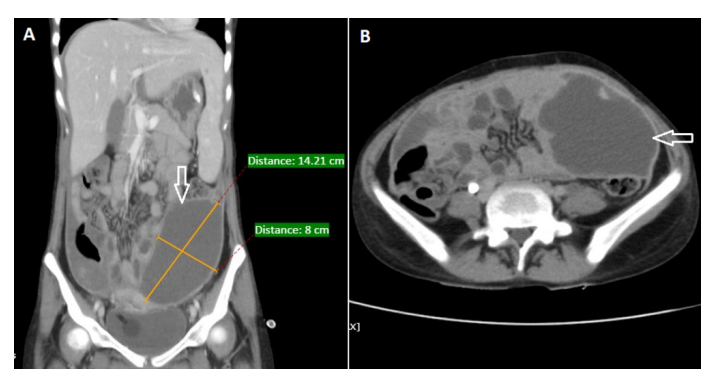

Figure 3 CECT abdomen (A-coronal, B-axial view) showing thick-walled multiloculated collection $(7.3 \times 8.4 \times 14.2 \mathrm{~cm})$ with thick internal septations in left lumbar and iliac fossa region(arrow). CECT, contrastenhanced CT. 


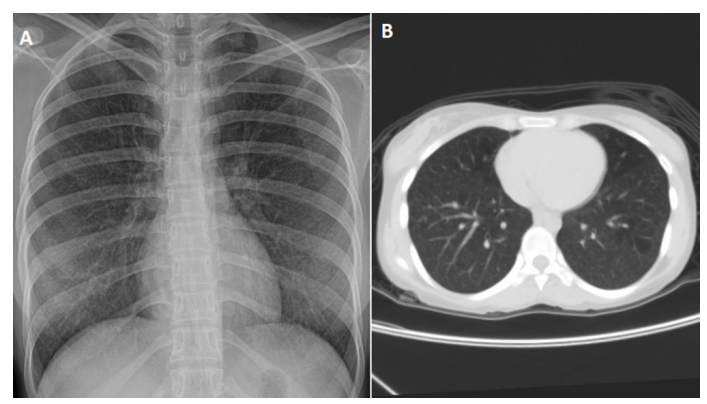

Figure 4 Follow-up chest X-ray (A) and CT chest (B-axial view) after 3 months of antitubercular therapy showing complete resolution.

often delayed in disseminated tuberculosis especially when

\section{Learning points}

- Disseminated and miliary tuberculosis are generally associated with HIV and AIDS, but rarely they can also occur in immunocompetent individuals.

- Common presenting symptoms in patients with disseminated and miliary tuberculosis are fever, anorexia, weight loss, fatigue, cough and so on. Acute presentations like seizures are extremely rare in such cases.

- A high index of clinical suspicion and efforts towards early diagnosis and initiation of antitubercular therapy are required to prevent complications. there are atypical presentations. A miliary pattern on a chest radiograph is the radiographic hallmark of miliary tuberculosis. MRI brain with contrast is the investigation of choice to diagnose a tuberculoma. The characteristic finding is the nodular enhancing lesion with central hypointensity. Other imaging modalities like ultrasonography, CECT may be required to rule out abdominal and pelvic involvement. Disseminated and miliary tuberculosis are generally associated with HIV and AIDS, hence immunodeficiency status should be ruled out in all such cases. ${ }^{3}$

Antitubercular therapy should be initiated as soon as the diagnosis is made. Associated central nervous system involvement mandates prolonged treatment for at least 12 months. ${ }^{4}$

Contributors SPM: wrote the draft of the manuscript. VG and AD: involved in the revision of the manuscript. RVA: involved in patient management and revised the manuscript critically for important intellectual content. All authors: contributed to the literature review and approved the final manuscript for submission.

Competing interests None declared.

Patient consent Obtained.

Provenance and peer review Not commissioned; externally peer reviewed.

(C) BMJ Publishing Group Ltd (unless otherwise stated in the text of the article) 2017. All rights reserved. No commercial use is permitted unless otherwise expressly granted.

\section{REFERENCES}

1 WHO. Global tuberculosis report. 2015.

2 Wang JY, Hsueh PR, Wang SK, et al. Disseminated tuberculosis: a 10-year experience in a medical center. Medicine 2007:86:39-46.

3 Sharma SK, Mohan A. Disseminated and Miliary Tuberculosis. In: Sharma SK, Mohan A, eds. Tuberculosis. 2nd edn. New Delhi: Jaypee Brothers Medical Publishers, 2009:493.

4 Treatment of tuberculosis: guidelines. 4th edn. Geneva: World Health Organization, 2010.

Copyright 2017 BMJ Publishing Group. All rights reserved. For permission to reuse any of this content visit http://group.bmj.com/group/rights-licensing/permissions.

BMJ Case Report Fellows may re-use this article for personal use and teaching without any further permission.

Become a Fellow of BMJ Case Reports today and you can:

- Submit as many cases as you like

- Enjoy fast sympathetic peer review and rapid publication of accepted articles

- Access all the published articles

Re-use any of the published material for personal use and teaching without further permission

For information on Institutional Fellowships contact consortiasales@bmjgroup.com

Visit casereports.bmj.com for more articles like this and to become a Fellow 